Analisis Perbandingan... (Syahrul)

\title{
ANALISIS PERBANDINGAN KINERJA PERUSAHAAN DOMESTIK DAN ASING DENGAN MENGGUNAKAN ANALISIS RASIO MODAL SAHAM
}

\author{
Syahrul Syarifudin \\ syahrul.syarifudin@uniku.ac.id \\ Teti Rahmawati \\ teti.rahmawati@uniku.ac.id \\ Fakultas Ekonomi Universitas Kuningan
}

\begin{abstract}
There are companies that stand in Indonesia that are owned by foreigners. People tend to judge that the performance of foreign companies is better than domestic companies. This is due to the assumption that foreign companies have relatively larger capital, technology, and expertise that is better than domestic companies. Another presumption is that before, during, and after the crisis the performance of foreign-owned companies is better than domestic companies. In addition, to find out the good and bad performance of a company, it can use a stock capital ratio analysis. With this stock capital ratio, it can be seen the rate of return on equity, the ratio of earning per share, profit price, capitalization rate, and dividend income. So that the analysis can help investors and potential investors as sources of information support in investing in the company. The results of the data analysis using the T-test (Difference Test) found that there was no significant difference between the return on equity ratio, earnings per share ratio, the profit price ratio, the capitalization rate and dividend income. Thus the performance of domestic companies is significantly similar to the performance of foreign companies.
\end{abstract}

Keywords: Earning per share, profit ratio, , capitalization ratio

\section{PENDAHULUAN}

Indonesia merupakan salah satu negara berkembang, dimana salah satu faktor pendukung berkembangnya suatu negara adalah dari bidang ekonomi. Di bidang ekonomi inilah tentunya yang

berkaitan dengan banyaknya berdirinya perusahaan besar maupun perusahaan kecil. Perusahaan yang berdiri itu bisa milik asing maupun domestik dengan modal kecil maupun modal yang sangat besar. Masyarakat cenderung menilai bahwa kinerja perusahaan asing lebih baik dibandingkan dengan perusahaan domestik. Hal ini, disebabkan adanya anggapan bahwa perusahaan asing mempunyai modal yang relatif lebih besar, teknologinya, serta keahlian yang dimiliki lebih baik dibandingkan dengan perusahaan domestik. Anggapan lainnya yaitu pada saat sebelum, semasa, dan setelah krisis kinerja perusahaan milik asing lebih 
JRKA Volume 5 Isue 1, Februari 2019: 96 - 108

baik dibandingkan kinerja perusahaan domestik.

Pada saat sebelum krisis perekonomian Indonesia sangat baik sehingga kinerja perusahaan pun baik. Namun pada saat krisis dimana perekonomian Indonesia sedang buruk sehingga kinerja perusahaan pun sangat buruk. Hal ini, disebabkan karena biaya bahan baku, biaya produksi, dan biaya pemasaran menjadi sangat mahal. Sedangkan setelah krisis perekonomian Indonesia sudah menjadi baik kembali sehingga kinerja perusahaanpun kembali menjadi baik pula.

Selain itu, berhasil atau tidaknya suatu perusahaan pada

umumnya ditandai dengan kemampuan manajemen dalam melihat kemungkinan dan kesempatan dimasa yang akan datang baik jangka pendek maupun jangka panjang. Oleh karena itu, adalah tugas manajemen untuk merencanakan masa depan perusahaannya, agar sedapat mungkin semua semua kemungkinan dan kesempatan dimasa yang akan datang telah disadari dan telah direncanakan cara menghadapi sejak sekarang.

Perencanaan pada dasarnya merupakan kegiatan membentuk masa depan sekarang. Kegiatan pokok

manajemen dalam perencanaan perusahaan adalah memutuskan sekarang berbagai macam alternatif dan perumusan kebijakan yang akan dilaksanakan dimasa yang akan datang.

Ukuran yang sering dipakai untuk menilai berhasil atau tidaknya manajemen suatu perusahaan adalah laba bersih yang terdapat di dalam laporan keuangan perusahaan. Laporan keuangan tidak hanya ditujukan bagi pihak internal perusahaan tetapi juga bagi pihak eksternal perusahaan. Setiap elemen laporan keuangan akan mempunyai makna yang lebih bila dianalisis dengan berbagai model yang tersedia dengan kebutuhan pemakai informasi. Manajemen merupakan pihak yang bertanggung jawab tentang pencapaian tujuan perusahaan maka dengan sendirinya manajemen berkepentingan untuk mengetahui, mengukur, merencanakan dan mengendalikan semua resiko keuangan.

Oleh karena itu, manajer pada suatu perusahaan, harus mempunyai alat yang dapat membuat investor percaya bahwa dananya akan lebih produktif dan menguntungkan bila ditanam dalam perusahaan mereka.

Pihak manajemen juga harus meningkatkan kualitas dan kinerja perusahaan. Termasuk dalam lingkup tanggung jawab tersebut, manajemen harus menciptakan rasio keuangan yang sehat sehingga dapat memberikan jaminan pencapaian kepentingan semua pihak, baik internal maupun eksternal.

Modal saham merupakan salah satu bagian dari laporan keuangan

pada Perseroan Terbatas. Pihak manajemen harus melaporkan keadaan perusahaan kepada para pemegang saham. Pemegang saham sebagai investor sangat berkepentingan dalam sebuah perusahaan, yaitu untuk mengetahui apakah mereka akan mendapatkan keuntungan atau mendapatkan resiko dalam 
menanamkan dananya dalam sebuah perusahaan dengan menggunakan analisis rasio keuangan perusahaan. Salah satu teknik yang digunakan untuk penyajian analisis ini adalah rasio modal saham.

Bagi pihak manajemen hasil analisis ini menjadi sangat penting karena dengan menggunakan pendekatan analisis tersebut kinerja manajemen dapat diukur dan dievaluasi, baik dalam satu periode berjalan maupun dalam satu siklus operasi tahunan secara berturut-turut.

Sebagaimana halnya pihak manajemen, pihak-pihak luar perusahaan juga dapat mengetahui kinerja dan menilai prospek sebuah perusahaan baik jangka pendek maupun jangka panjang. Tujuan dari penelitian ini adalah :

1. Untuk mengetahui kinerja keuangan perusahaan domestik pada saat sebelum krisis, saat krisis dan setelah krisis dengan menggunakan rasio modal.

2. Untuk mengetahui kinerja keuangan perusahaan asing pada saat sebelum krisis, saat krisis dan setelah krisis dengan menggunakan rasio modal.

3. Untuk mengetahui perbedaan kinerja keuangan perusahaan asing dan domestik.

\section{KERANGKA TEORITIS DAN HIPOTESIS}

\section{Rasio Keuangan}

Setiap elemen laporan
keuangan akan menjadi lebih
bermakna bila dianalisis lebih jauh
dengan berbagai model yang tersedia

sesuai dengan kebutuhan para pamakai informasinya. Rasio adalah memperbandingkan suatu hal dengan hal lainnya sehingga dapat menunjukkan hubungan atau korelasi. Rasio keuangan merupakan suatu cara yang membuat perbandingan data keuangan perusahaan manjadi lebih berarti. Rasio keuangan menjadi dasar untuk menjawab pertanyaan penting mengenai kesehatan keuangan dari perusahaan. Pertanyaan tersebut meliputi likuiditas perusahaan, kemampuan manajemen memperoleh laba dari penggunaan aktiva perusahaan, dan kemampuan manajemen mendanai investasinya, serta hasil yang dapat diperoleh para pemegang saham dari investasi yang dilakukannya kedalam perusahaan.

Bentuk rasio keuangan dapat dibuat sesuai dengan kebutuhan analisis, analisis rasio keuangan pada dasarnya terdiri atas dua macam perbandingan yaitu:

1. Dengan cara memperbandingkan rasio keuangan dari satu perusahaan tertentu dengan rasio keuangan yang sama dari perusahaan lain yang sejenis dalam waktu yang sama.

2. Dengan cara memperbandingkan rasio waktu tertentu dengan rasio dari waktu sebelumnya pada perusahaan yang sama. Cara ini akan memberikan informasi perusahaan rasio dari waktu ke waktu sehingga bisa diketahui perkembangan nya dan untuk proyeksi pada masa yang akan datang. 
JRKA Volume 5 Isue 1, Februari 2019: 96 - 108

Menurut Gill ( 2003: 36 ), rasio keuangan terbagi atas empat jenis model rasio yaitu :

1. Rasio Likuiditas ( Liquidity Ratio ) Rasio ini digunakan untuk mengukur jumlah uang yang tersedia untuk membayar biaya jangka pendek maupun jangka panjang.

2. Rasio Profitabilitas ( Profitability Ratio )

Rasioinidigunakanuntuk mengukur dan membantu mengendalikan pendapatan, yaitu dengan cara memperbesar penjualan, memperbesar margin, mendapatkan manfaat yang lebih besar dari pengeluaran biaya-biaya, dan atau kombinasi ketiga hal ini.

3. Rasio Efisiensi (Efficiency Ratio ) Rasio ini digunakan untuk mengukur dan mengendalikan operasi perusahaan. Rasio ini melengkapi rasio lainnya untuk membantu perusahaan meningkatkan pendapatan dengan menilai transaksi-transaksi penting, seperti penggunaan pinjaman, pengendalian persediaan, dan manajemen asset.

4. Rasio Modal saham

Rasio ini digunakan terutama oleh investor untuk menentukan apakah ia membeli saham sebuah perusahaan atau tidak.

Dari keempat jenis rasio diatas yang akan dibahas lebih lanjut pada penulisan ini adalah rasio yang terakhir yaitu rasio modal saham yang berkaitan dengan investor.
Rasio Modal Saham ( Market Ratio ) Laporan keuangan perusahaan koorporasi meliputi modal saham. Manajemen perusahaan koorporasi harus melaporkan keadaan perusahaan kepada pemilik, yaitu para pemegang saham. Salah satu teknik yang digunakan adalah rasio modal saham atau biasa disebut rasio pasar ( market ratio ).Rasio pasar merupakan perhitungan keuangan yang digunakan oleh para investor untuk mengevaluasi kinerja perusahaan go public. Para pemegang saham sebagai investor sangat berkepentingan pada analisis rasio keuangan perusahaan.

Dalam proses memulai suatu bisnis, seluruh uang yang berasal dari penjualan saham akan terlihat pada " Modal Pemegang Saham “ sebagai modal disetor atau saham biasa, dan pada " Aktiva Lancar " sebagai kas. Selama perusahaan berjalan, mungkin sebagian jumlah uang tersebut dimasukkan dalam " Laba Ditahan " ( Gill, 2003: 68 ).

Rasio modal saham atau rasio pasar ini terbagi dalam beberapa jenis rasio yang terdiri dari :

\section{Laba atas Ekuitas ( Return on Equity / ROI )}

Laba atas ekuitas digunakan untuk mengukur besarnya pengembalian terhadap investasi para pemegang saham. Angka tersebut menunjukkan seberapa baik manajemen memanfaatkan investasi para pemilik saham.

\section{Rasio rendah :}

Menunjukkan bahwa para pemilik atau investor sebenarnya bisa menghasilkan lebih banyak uang 
jika melakukan investasi ditempat lain. Namun demikian, rasio ini harus dipertimbangkan dalam sudut pandang apa yang sedang terjadi selama siklus usaha yang sedang berlangsung, seperti perluasan usaha, hutang atau perubahan ekonomi.

\section{Rasio tinggi :}

Berarti manajemen telah melakukan tugasnya dengan baik. Pada umumnya, semakin tinggi rasio semakin baik.

\section{Rasio Pendapatan Per lembar Saham}

Rasio pendapatan per lembar saham digunakan untuk mengukur keberhasilan manajemen dalam mencapai keuntungan bagi para pemilik perusahaan. Angka tersebut adalah jumlah yang disediakan bagi para pemegang saham umum setelah dilakukan pembayaran seluruh biaya dan pajak untuk periode akuntansi terkait.

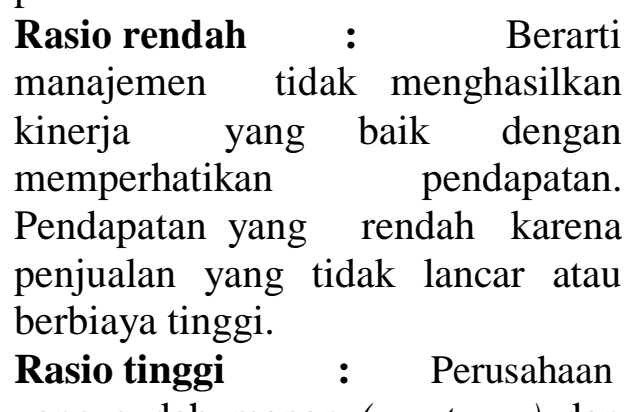
yang sudah mapan ( mature) dan atau yang memiliki lembar saham yang terbatas.

Sangat bergantung pada keadaan ekonomi secara umum, industri khusus, usia perusahaan, dan jumlah saham yang beredar.

Biasanya, para pemegang saham

kurang menyukai penurunan pendapatan perlembar saham. Penurunan pendapatan perlembar saham menunjukkan adanya penurunan laba perusahaan dan menyita perhatian lebih banyak terhadap pertumbuhan dan profitabilitas perusahaan. Sebaliknya, peningkatan pendapatan perlembar saham dianggap baik sepanjang peningkatan tersebut diikuti dengan harapan pasar.

\section{Rasio Harga Laba ( Price Earning Ratio )}

Rasio harga laba digunakan untuk mengukur seberapa banyak para investor bersedia membayar untuk setiap rupiah dari laba yang dilaporkan.

Rasio Rendah : Berarti para investor tidak akan mau membayar terlalu banyak untuk selembar saham. Para pemegang saham potensial akan berpikir bahwa perusahaan terlalu riskan. Namun demikian, jika seorang investor menginginkan saham ini dan yakin bahwa saham ini akan berkenbang, maka semakin rendah rasio semakin baik bagi investor tersebut. Rasio yang rendah bisa juga berarti belum berkembangnya pasar yang baik untuk saham ini.

Rasio tinggi : Membuat para investor yakin bahwa perusahaan memiliki tingkat pertumbuhan yang potensial tinggi. Namun jika rasionya terlalu tinggi, investor mungkin akan mencari sesuatu yang lebih beralasan. 
Rasio harga laba ( PER ) merupakan rasio yang sangat umum dipergunakan untuk mengevaluasi perusahaan saat ini. Rasio ini dan berbagai rasio lainnya memberikan suatu indikasi bagi manajemen mengenai apa yang dipikirkan aleh para investor tentang perusahaankinerjanya saat ini, di masa lalu, dan di masa mendatang. Pada umumnya, jika seluruh rasio memperlihatkan kinerja yang baik dan stabil, maka nilai sahamnya akan tinggi. Rasio ini untuk perusahaan go public tercantum dalam beberapa surat kabar.

\section{Rasio Tingkat Kapitalisasi}

Rasio tingkat kapitalisasi digunakan untuk mengukur tingkat pengembalian yang dituntut oleh pasar terhadap perusahaan. Jika rasio harga laba meningkat, maka tingkat kapitalisasi akan menurun.

Rasio rendah : Berarti para investor tidak menuntut tingkat pengembalian yang sangat tinggi

atas uang mereka karena beranggapan bahwa perusahaan tersebut akan menjadi suatu investasi yang baik.

Rasio tinggi : Berarti para investor menginginkan tingkat pengembalian yang tinggi untuk setiap dollar yang diinvestasikan. Dengan kata lain, dibutuhkan pengeluaran yang besar untuk menarik para investor.

Perusahaan yang memiliki pertumbuhan pendapatan yang tinggi umumnya memiliki biaya yang tinggi sehubungan dengan pendapatan, dan demikian pula sebaliknya. Tingkat kapitalisasi melaporkan hal ini sebagai presentase pengembalian berdasarkan pada harga jual per lembar saham dan jumlah yang diperoleh perusahaan untuk saham tersebut.

\section{Rasio Pendapatan Deviden}

Rasiopendapatandeviden

digunakan untuk mengukur hubungan antara deviden kas yang dibayarkan kepada pemegang saham biasa dan harga pasar per lembar saham biasa.

Rasio rendah : Tingkat laba investasi saham yang rendah. Peningkatan laba dapat dilakukan dengan menjual saham dan membeli pendapatan investasi yang lebih tinggi.

Rasio tinggi : Investasi yang bagus. Sepanjang pendapatan deviden tetap tinggi, tidak diperlukan perubahan pada investasi.

Deviden merupakan suatu hal pentinr bagi para pemegang saham yang bergantung pada deviden perusahaan untuk pendapatan kas yang tetap. Secara umum, semakin tinggi pendapatan deviden semakin rendah modal yang diraih melalui peeningkatan harga saham. Para investor merespon sangat negatif ketika sebuah perusahaan mengurangi devidennya, karena secara umum pembayaran deviden yang 
dikurangi, akan diikuti oleh penurunan harga pasar per lembar saham.

\section{METODOLOGI PENELITIAN}

\section{Metode Penelitian}

Penelitian ini menggunakan metode deskriptif yang mengkhususkan pada studi komparatif merupakan suatu penelitian yang mencari jawaban secara mendasar tentang sebab akibat dengan menganalisis faktor-faktor penyebab terjadinya atau munculnya suatu fenomena tertentu. Metode komparatif adalah suatu metode penelitian yang bersifat membandingkan keberadaan satu variabel atau lebih pada dua atau lebih sampel yang berbeda atau pada waktu yang berbeda (Sugiyono, 2010:54). Melalui metode ini, dapat diperoleh perbandingan mengenai relevansi atas komparasi kinerja keuangan perusahaan sebelum dan sesudah krisis ekonomi.

\section{Operasionalisasi Variabel \\ Penelitian}

Variabel penelitian pada dasarnya adalah segala sesuatu yang berbentuk apa saja yang ditetapkan oleh penelitian untuk dipelajari sehingga diperoleh informasi tentang hal tersebut, kemudian ditarik

kesimpulannya. Adapun definisi operasional yakni penentuan construct sehingga menjadi variabel yang dapat diukur. Definisi operasional diperlukan agar konsep yang digunakan dapat diukur secara empiris serta menghindari terjadi kesalahan penafsiran yang berbeda.
Beberapa variabel dalam penelitian ini adalah rasio keuangan yang dapat dijadikan tolak ukur penilaian kinerja keuangan perusahaan dan sebagai dasar perbandingan kinerja keuangan perusahaan, antara lain :

\section{Laba atas Ekuitas ( Return on Equity / ROE )}

Laba atas ekuitas digunakan untuk mengukur besarnya pengembalian terhadap investasi para pemegang saham. Angka tersebut menunjukkan seberapa baik manajemen memanfaatkan investasi para pemilik saham.

Rasio Pendapatan Per lembar Saham ( Earning per Share )

Rasio pendapatan per lembar saham digunakan untuk mengukur keberhasilan manajemen dalam mencapai keuntungan bagi para pemilik perusahaan. Angka tersebut adalah jumlah yang disediakan bagi para pemegang saham umum setelah dilakukan pembayaran seluruh biaya dan pajak untuk periode akuntansi terkait.

\section{Rasio Harga Laba ( Price Earning Ratio )}

Rasio harga laba digunakan untuk mengukur seberapa banyak para investor bersedia membayar untuk setiap rupiah dari laba yang dilaporkan.

\section{Rasio Tingkat Kapitalisasi}

Rasio tingkat kapitalisasi digunakan untuk mengukur tingkat pengembalian 
JRKA Volume 5 Isue 1, Februari 2019: 96 - 108

yang dituntut oleh pasar terhadap perusahaan. Jika rasio harga laba meningkat, maka tingkat kapitalisasi akan menurun.

Rumus:

\section{Rasio Pendapatan Deviden (Deviden Yield )}

Rasio pendapatan deviden digunakan untuk mengukur hubungan antara deviden kas yang dibayarkan kepada pemegang saham biasa dan harga pasar per lembar saham biasa.

\section{Populasi dan Sampel}

\begin{tabular}{lcr}
\multicolumn{2}{c}{ Adapun dalam } & penentuan \\
sampel & menggunakan & teknik \\
purposive & sampling, & menuru
\end{tabular} Sugiyono (2010:68) purposive sampling yaitu "teknik penentuan sampel dengan pertimbangan tertentu".Purposive sampling dilakukan dengan cara mengambil subjek bukan didasarkan atas strata, random atau daerah tetapi didasarkan pada tujuan tertentu dan teknik ini biasanya dilakukan karena pertimbangan keterbatasan waktu, tenaga dan dana sehingga tidak bisa mengambil sampel yang besar dan jauh. Dalam penelitian ini, sampel yang diambil adalah laporan keuangan dari 10 perusahaan yaitu PT. Komatsu Indonesia Tbk, PT. Lion Metal Works Tbk, PT. Jemblo Cable Tbk, PT. Sari Husada Tbk, dan PT. Eratex Djaja LTD Tbk, PT. Delta Djakarta Tbk, PT. Aqua Golden Mississippi Tbk, PT. Indofood Sukses Makmur Tbk, PT. Mayora Indah Tbk, dan PT. Ultrajaya Milk Tbk.

\section{HASIL PENELITIAN DAN PEMBAHASAN}

Analisis rasio modal saham untuk menilai kinerja perusahaan dalam mencapai keuntungan bagi para investor kasus PT. Dankos Laboratories, Tbk adalah rasio modal saham perusahaan berada diatas rasio rata-rata industri farmasi, yaitu untuk rasio laba atas ekuitas ( $\mathrm{ROE}$ ), rasio pendapatan perlembar saham ( EPS ), rasio harga laba ( PER ) dan rasio

pendapatan deviden mengalami kenaikan.

Kenaikan dari ke empat rasio tersebut menunjukkan bahwa kinerja manajemen perusahaan sudah cukup baik dan perusahaan memiliki tingkat pertumbuhan yang potensial tinggi. Sedangkan untuk rasio tingkat kapitalisasi berada dibawah rasio ratarata industri farmasi. Hal ini disebabkan karena meningkatnya rasio harga laba ( PER ), hal tersebut menunjukkan bahwa perusahaan telah memiliki tingkat pertumbuhan yang potensial tinggi. Penurunan tingkat kapitalisasi menunjukkan bahwa para investor tidak menuntut tingkat pengembalian yang terlalu tinggi atas uang mereka karena beranggapan bahwa perusahaan tersebut akan menjadi suatu investasi yang baik (Lukman, 2001). 


\section{Analisis Data Uji Normalitas Data}

\section{Tabel 1}

Uji Normalitas Data Awal Gabungan

One-Sample Kolmogorov-Smirnov Test

\begin{tabular}{|c|c|c|c|c|c|c|}
\hline & ROE-Dom & EPS-Dom & PER-Dom & TK-Dom & DY-Dom \\
\hline \multicolumn{2}{|l|}{$\mathrm{N}$} & 10 & 10 & 10 & 10 & 10 \\
\hline$a, b$ & Mean & .28400 & 238.12900 & 14.96900 & .09100 & .03200 \\
\hline Normal Parameters ${ }^{a, 0}$ & Std. Deviation & .218998 & 141.547776 & 7.154780 & .061001 & .013984 \\
\hline & Absolute & .244 & .149 & .249 & .249 & .184 \\
\hline Most Extreme Differences & Positive & .244 & .149 & .127 & .249 & .184 \\
\hline & Negative & -.153 & -.100 & -.249 & -.202 & -.143 \\
\hline Kolmogorov-Smirnov Z & & .770 & .471 & .788 & .788 & .581 \\
\hline Asymp. Sig. (2-tailed) & & .593 & .980 & .563 & .563 & .889 \\
\hline
\end{tabular}

a. Test distribution is Normal.

b. Calculated from data.

\section{Sumber: Data sekunder yang diolah}

Uji normalitas digunakan untuk mengetahui apakah populasi data berdistribusi normal atau tidak. Uji ini biasanya digunakan untuk mengukur data berskala ordinal, interval, ataupun rasio. Jika analisis menggunakan metode prametrik, maka persyaratan normalitas harus terpenuhi, yaitu data berasal dari distribusi yang normal. Jika data tidak berdistribusi normal, atau jumlah sampel sedikit dan jenis data adalah nominal atau ordinal maka metode yang digunakan adalah

statistik nonparametrik. Dalam pembahasan ini akan digunakan uji One Sample Kolmogorov-smirnov dengan menggunakan taraf signifikan 0,05 . Data dinyatakan berdistribusi normal jika signifikan lebih besar dari 5\% atau 0,05 (Priyanto, Duwi: 2008).

Hasil pengujian normalitas pada pengujian terhadap 10 data menunjukkan bahwa seluruh variabel sudah berdistribusi normal yang ditunjukkan nilai signifikasi dari ROE sebesar 0,593, EPS sebesar 0,980, PER sebesar 0,563, dan DY sebesar 0,889 hasil pengujian Kolmogorov- Smirnov tersebut lebih besar dari 0,05.

Pengujian Hipotesis

Uji hipotesis yang digunakan dalam pengujian ini adalah independent sample t-Test. Alasan pemilihan alat uji ini karena t-Test merupakan suatu uji dari keseimbangan dua distribusi populasi. Uji t-Test ini digunakan untuk mengetahui apakah terdapat perbedaan antara dua kelompok sampel yang diteliti. Data yang digunakan biasanya berskala interval atau rasio.

Berdasarkan hasil penelitian yang telah dilakukan, setelah melalui tahap pengumpulan data, pengolahan data, analisis data dan yang terakhir interpretasi hasil analisis mengenai perbedaan yang signifikan rasio laba atas ekuitas (ROE), rasio pendapatan per lembar saham (EPS), rasio harga laba (PER), rasio tingkat kapitalisasi, rasio pendapatan deviden antara 
perusahaan domestik dengan perusahaan asing. Dengan menggunakan data yang terdistribusi normal, maka dihasilkan kesimpulan sebagai berikut:

1. Dari hasil analisis data secara uji Ttest (Uji Beda) diperoleh bahwa tidak terdapat perbedaan yang signifikan antara ROE perusahaan domesik dengan ROE perusahaan asing. Pengujian hipotesis ditemukan bahwa nilai probabilitas sig 0,263 yang berarti sig > 0,05 maka H1 ditolak berarti variabel ROE mempunyai varian yang sama (identik). Dengan demikian kinerja perusahaan domestik dalam menghasilkan keuntungan yang akan digunakan untuk menutup investasi yang dikeluarkan sama secara signifikan dari kinerja perusahaan asing.

2. Dari hasil analisis data secara uji Ttest (Uji Beda) diperoleh bahwa tidak terdapat perbedaan yang signifikan antara EPS perusahaan domesik dengan EPS perusahaan asing. Pengujian hipotesis ditemukan bahwa nilai probabilitas sig 0,262 yang berarti sig > 0,05 maka $\mathrm{H} 2$ ditolak berarti variabel EPS mempunyai varian yang sama (identik). Dengan demikian kinerja perusahaan domestik dalam menghasilkan laba untuk setiap lembar saham biasa perusahaan yang beredar sama secara signifikan dari kinerja perusahaan asing.

3. Dari hasil analisis data secarauji Ttest (Uji Beda) diperoleh bahwa tidak terdapat perbedaan yang signifikan antara PER perusahaan domestik dengan PER perusahaan asing. Pengujian hipotesis ditemukan bahwa nilai probabilitas sig 0,355 yang berarti sig > 0,05 maka $\mathrm{H} 3$ diterima berarti variabel PER mempunyai varian yang sama ( identik). Dengan demikian kinerja perusahaan domestik dalam menghasilkan laba untuk setiap lembar saham biasa perusahaan yang beredar dan untuk menutup investasi yang dikeluarkan sama secara signifikan dari kinerja perusahaan asing.

4. Dari hasil analisis data secar auji Ttest (Uji Beda) diperoleh bahwa tidak terdapat perbedaan yang signifikan antara Tingkat Kapitalisasi perusahaan domestik denganTingkatKapitalisasi perusahaan asing. Pengujian hipotesis ditemukan bahwa nilai probabilitas sig 0,12 yang berarti sig > 0,05 maka H4 ditolak berarti variabel Tingkat Kapitalisasi mempunyai varian yang sama (identik). Dengan demikian kinerja perusahaandomestikdalam

menghasilkan pengembalian keuntungan yang akan digunakan berdasarkan pada harga jual per lembar saham dan jumlah yang diperoleh perusahaan untuk saham tersebut sama secara signifikan dari kinerja perusahaan asing.

5. Dari hasil analisis data secarauji Ttest (Uji Beda) diperoleh bahwa tidak terdapat perbedaan yang signifikan antara Pendapatan Deviden perusahaan domestik denganTingkatKapitalisasi perusahaan asing. Pengujian hipotesis ditemukan bahwa nilai probabilitas sig 0,399 yang berarti 
sig > 0,05 maka H5 ditolak berarti

variabel Tingkat Kapitalisasi

mempunyai varian yang sama (identik). Dengan demikian kinerja

perusahaan domestik dalam

menghasilkan deviden kas yang dibayarkan kepada pemegang saham biasa dan harga pasar per lembar saham biasa untuk saham tersebut sama secara signifikan dari kinerja perusahaan asing.

\section{Saran}

Dari adanya keterbatasan penelitian yang telah dikemukan, maka diharapkan pada peneliti selanjutnya untuk:

1. Dapat menggunakan variabel lain dalam mengukur kineja keuangan.

2. Dapat menggunakan data yang terbaru agar dapat diperoleh informasi terbaru mengenai kondisi keuanagan perusahaan yang di jadikan sampel.

3. Untuk memperoleh hasil penelitian yang maksimal sesuai dengan yang diharapkan, penelitianselanjutnya sebaiknyamenggunakans ampel yang besar dari penelitian sekaran 


\section{DAFTAR PUSTAKA}

\section{Buku-buku:}

Baridwan, Z. Intermediate Accounting. Ed - 7, BPFE Universitas Gajah Mada, Yogyakarta : BPFE, 1997.

Djarwanto, Ps. Pokok-Pokok Analisis Laporan Keuangan, Edisi-2. Yogyakarta : BPFE, 2004.

Fakhruddin, M \& M. Sopyan Hadiyanto. Perangkat Dan Modal Analisis Investasi Di Pasar Modal. Jakarta : PT. Elex Media Computindo, 2001.

Gill, James O. \& Moira Chantton. Memahami L aporan Keuangan. Penerjemah : Dwi Prabaningtyas. Jakarta : PPM, 2003.

Kasmir. Bank dan Lembaga Keuangan Lainnya. Ed-6. Jakarta : PT. RajaGrafindo Persada, 2002.
Munawir, S. Analisis Laporan Keuangan. Lyberty, Yogyakarta, 2001.

Sawir, A. Analisis Kinerja Keuangan dan Perencanaan Keuangan Perusahaan. Jakarta : PT. Gramedia Pustaka Utama, 2003.

Sjahrir. Analisis Pasar Modal. Jakarta : Pustaka Sinar Harapan, 2002.

Sugiono. Metode Penelitian Kuantitatif Kualitatif dan RD. Cet. VI; Bandung: Alfabeta, 2009.

Usman, Marzuki, dkk., ABC Pasar Modal Indonesia, Jakarta : Institut Bankir Indonesia, 1994.

\section{Jurnal Penelitian :}

Lukman, Hendro. “ Analisis Rasio Dalam Menganalisis Tujuan Akuisisi Suatu Perusahaaan “ Fakultas.Ekonomi Universitas Tarumanegara, Tahun V, No. 1, 2001. 